\title{
Completeness of tuberculosis reporting forms in five Brazilian capitals with a high incidence of the disease*
}

\author{
Completude das fichas de notificações de tuberculose em cinco capitais do \\ Brasil com elevada incidência da doença
}

\author{
Normeide Pedreira dos Santos, Monique Lírio, Louran Andrade Reis Passos, \\ Juarez Pereira Dias, Afrânio Lineu Kritski, Bernardo Galvão-Castro, \\ Maria Fernanda Rios Grassi
}

\begin{abstract}
The aim of this study was to evaluate the completeness of tuberculosis reporting forms in the greater metropolitan areas of five Brazilian capitals where the incidence of tuberculosis was high in 2010-Salvador, Rio de Janeiro, Cuiabá, Porto Alegre, and Belém-using tabulations obtained from the Sistema Nacional de Informação de Agravos de Notificação (National Case Registry Database). The degree of completeness was highest in Porto Alegre and Cuiabá, whereas it was lowest in Rio de Janeiro, where there are more reported cases of tuberculosis than in any other Brazilian capital. A low degree of completeness of these forms can affect the quality of the Brazilian National Tuberculosis Control Program, which will have negative consequences for health care and decision-making processes.
\end{abstract}

Keywords: Tuberculosis; Public health surveillance; Disease notification.

\section{Resumo}

0 objetivo deste estudo foi avaliar a completude das fichas de notificações de tuberculose de cinco capitais brasileiras com alta incidência regional de tuberculose em 2010 - Salvador, Rio de Janeiro, Cuiabá, Porto Alegre e Belém - através dos relatórios de tabulação do Sistema Nacional de Informação de Agravos e Notificações. Porto Alegre e Cuiabá apresentaram os melhores resultados, enquanto o Rio de Janeiro, capital com o maior número de notificações de tuberculose no país, apresentou o pior. A baixa completude desses formulários pode comprometer a qualidade do Programa Nacional de Controle da Tuberculose e repercutir na assistência e nos processos decisórios.

Descritores: Tuberculose; Vigilância da população; Notificação de doenças.

It is estimated that, on an annual basis, there are eight million new cases of tuberculosis and two million related deaths. More than 95\% of all cases occur in developing countries..$^{(1)}$ Brazil ranks 17th among the 22 countries with the highest annual incidence of tuberculosis, ${ }^{(2)}$ at 32 cases $/ 100,000$ population. The incidence of tuberculosis in the country varies by geographic region, the lowest rates occurring in the central-west, southern, and northeastern regions $(21.90,33.18$, and
38.77 cases/100,000 population, respectively). In southeastern Brazil, the incidence is $40.98 / 100,000$ population, whereas, in northern Brazil, it is $47.77 / 100,000$ population. The highest proportions of treatment dropout, HIV co-infection, incidence, and tuberculosis-related mortality occur in the capital cities. Among the Brazilian capitals, in their respective regions, the incidence rates are highest in Belém (northern Brazil; 94.09/100,000 population), Rio de Janeiro (southeastern Brazil;

\footnotetext{
* Study carried out under the auspices of the Graduate Program in Medicine and Health, Bahia School of Medicine and Public Health, and in the Advanced Laboratory of Public Health, Gonçalo Moniz Research Center, Oswaldo Cruz Foundation-Bahia, Salvador, Brazil.

Correspondence to: Maria Fernanda Rios-Grassi. Laboratório Avançado de Saúde Pública, Fundação Oswaldo Cruz-Bahia (F1OCRUZ-BA), Rua Waldemar Falcão, 121, Candeal, CEP 40296-710, Salvador, BA, Brasil.

Tel. 5571 9971-7961. E-mail: grassi@bahia.fiocruz.br

Financial support: Louran Andrade Reis Passos is the recipient of a Young Investigator Grant from the Programa Institucional de Bolsas de Iniciação Cientifica (PIBIC, Institutional Program for Scientific Initiation Scholarships) of the Fundação Oswaldo CruzBahia (FIOCRUZ-BA, Oswaldo Cruz Foundation-Bahia). Afrânio Lineu Kritski is the recipient of 1A Research Productivity Grant and Bernardo Galvão-Castro Filho is the recipient of a 1B Research Productivity Grant from the Brazilian Conselho Nacional de Desenvolvimento Científico e Tecnológico (CNPq, National Council for Scientific and Technological Development).

Submitted: 3 September 2012. Accepted, after review: 28 January 2013.
} 
89.42/100,000 population), Cuiabá (centralwest Brazil; 85.65/100,000 population), Salvador (northeastern Brazil; 72.62/100,000 population), and Porto Alegre (southern Brazil; 44.39/100,000 population). ${ }^{(3)}$

Tuberculosis is a disease for which reporting has been mandatory in Brazil since 1998. Reporting and follow-up forms are completed by the staff at the health care clinics in the cities and delivered to the Sistema de Informação de Agravos de Notificação (SINAN, Brazilian Case Registry Database) for processing. ${ }^{(4,5)}$ The completeness of the fields on the reporting forms can be considered a marker of quality, complete data sets making it possible to understand the dynamics of the disease, set intervention priorities, and assess the impact of the interventions implemented. (5) In order to reduce morbidity and mortality, as well as to improve tuberculosis control, the Programa Nacional de Controle da Tuberculose (PNCT, Brazilian National Tuberculosis Control Program) has classified certain cities as priority cities for tuberculosis control. Priority cities include all capital cities and any city with more than 100,000 inhabitants, as well as cities where the tuberculosis incidence is $\geq 80 \%$ above the national average or the annual tuberculosisrelated mortality rate is higher than $2.5 / 100,000$ population. ${ }^{(6)}$ Tuberculosis surveillance studies have demonstrated that, paradoxically, the degree of completeness of reporting forms is low in priority cities. ${ }^{(7,8)}$ The aim of the present study was to evaluate the completeness of tuberculosis reporting and follow-up forms in five Brazilian capitals.

To that end, we conducted a descriptive study in which we evaluated the SINAN database information for the Brazilian capitals of Belém, Rio de Janeiro, Cuiabá, Salvador, and Porto Alegre for the 2001-2010 period; applying the selection criterion of investigating the greater metropolitan areas of the capitals where the incidence of tuberculosis was highest in 2010. ${ }^{(3)}$ The information on the completeness of reporting forms was obtained from the SINAN tabulations, with automatic table generation, by two previously trained undergraduate investigators, under the supervision of the researchers. We excluded fields that read "omitted", "left blank", or "in progress". The variables of interest were grouped as follows: sociodemographic variables-gender, age group, and institutionalization; clinical variables-type of admission, clinical presentation of tuberculosis (pulmonary or extrapulmonary, and, in cases of extrapulmonary tuberculosis, whether it presented as a single-system or multisystem disease [classified in the present study as extrapulmonary tuberculosis 1 and 2, respectively]), and HIV co-infection; and diagnostic and follow-up variables-first and second smears, smears at 2 and 6 months of treatment, sputum culture, HIV serology, and treatment outcome. To analyze the completeness of the reporting forms, we used the SINAN qualitative evaluation system, with categories ranging from 1 to 4 , corresponding to completeness of $0.0-25.0 \%, 25.1-50.0 \%$, 50.1-75.0\%, and 75.1-100.0\%, respectively. ${ }^{(9)}$

In the 2001-2010 period, 160,719 cases of tuberculosis were reported in the capitals evaluated-82,604 in Rio de Janeiro, 34,118 in Salvador, 22,836 in Porto Alegre, 17,132 in Belém, and 4,029 in Cuiabá-accounting for $18 \%$ of all cases in Brazil. The variables "age group" and "gender" were classified as category 4 in all capitals, with a degree of completeness of nearly $100 \%$, whereas the field "institutionalization" was classified as category 2 in the five capitals, with a degree of completeness ranging from $31.6 \%$ to $48.4 \%$. Tables 1 and 2 show the rates of completeness for the different variables for the five capitals of interest.

The results of the present study show that, although more than $40 \%$ of the variables of interest were classified as category 4 (degree of completeness of 75.1-100.0\%), the proportion of variables for which the degree of completeness was low (categories 1 and 2) was high. In none of the capitals of interest were more than 70\% of the variables classified as category 4 , despite the recommendation of the National Pulmonology Health Care Council of the Brazilian National Ministry of Health for completeness of reporting forms. The degree of completeness was lowest in the cities of Rio de Janeiro and Belém, with almost 50\% of the variables being classified as categories 1 and 2, followed by Salvador, with $40 \%$, whereas it was highest in Porto Alegre and Cuiabá. These results confirm those of previous studies, which showed that surveillance quality was poor in one third of the Brazilian cities in the 2001-2003 period $^{(7)}$ and that the degree of completeness of reporting forms was lower in cities where there are more cases of tuberculosis. ${ }^{(7,8)}$ 
Table 1 - Completeness of tuberculosis reporting forms in the Brazilian capitals of Salvador, Rio de Janeiro, Cuiabá, Porto Alegre, and Belém, 2001-2010: clinical variables. ${ }^{a}$

\begin{tabular}{lccccc}
\hline \multirow{2}{*}{ Clinical variable } & \multicolumn{5}{c}{ Reporting forms completed } \\
\cline { 2 - 6 } & Salvador & Rio de Janeiro & Cuiabá & Porto Alegre & Belém \\
\cline { 2 - 6 } & $(\mathrm{n}=34,118)$ & $(\mathrm{n}=82,604)$ & $(\mathrm{n}=4,029)$ & $(\mathrm{n}=22,836)$ & $(\mathrm{n}=17,132)$ \\
\hline Type of admission & $34,006(99.7)$ & $82,604(100.0)$ & $4,025(99.9)$ & $22,831(99.9)$ & $16,986(99.1)$ \\
Clinical presentation & $34,06(99.7)$ & $82,604(100.0)$ & $4,025(99.9)$ & $22,831(99.9)$ & $16,986(99.1)$ \\
AIDS & $8,101(23.7)$ & $22,122(26.8)$ & $1,506(37.4)$ & $14,130(61.9)$ & $1,242(7.2)$ \\
Extrapulmonary 1 & $5,043(14.8)$ & $15,078(18.3)$ & $591(14.7)$ & $6,592(28.9)$ & $3,114(18.2)$ \\
Extrapulmonary 2 & $320(0.9)$ & $1,139(1.4)$ & $41(1.0)$ & $829(3.6)$ & $301(1.6)$ \\
\hline
\end{tabular}

avalues expressed as $n(\%)$. Source: Brazilian National Ministry of Health/Department of Health Surveillance/Brazilian Case Registry Database; data collated by the authors.

Table 2 - Completeness of tuberculosis reporting forms in the Brazilian capitals of Salvador, Rio de Janeiro, Cuiabá, Porto Alegre, and Belém, 2001-2010: diagnostic and follow-up variables. ${ }^{2}$

\begin{tabular}{lccccr}
\hline \multirow{2}{*}{ Variable } & \multicolumn{5}{c}{ Reporting forms completed } \\
\cline { 2 - 6 } & Salvador & Rio de Janeiro & Cuiabá & Porto Alegre & Belém \\
\cline { 2 - 6 } & $(\mathrm{n}=34,118)$ & $(\mathrm{n}=82,604)$ & $(\mathrm{n}=4,029)$ & $(\mathrm{n}=22,836)$ & $(\mathrm{n}=17,132)$ \\
\hline First smear & $34,006(99.7)$ & $82,604(100.0)$ & $4,025(99.9)$ & $22,831(99.9)$ & $16,986(99.1)$ \\
Second smear & $12,194(35.7)$ & $35,515(43.0)$ & $1,780(44.2)$ & $11,148(48.8)$ & $6,948(40.5)$ \\
Smear at 2 months & $18,701(54.8)$ & $20,044(24.3)$ & $3,551(88.1)$ & $22,175(97.1)$ & $7,458(43.5)$ \\
Smear at 6 months & $16,071(47.1)$ & $19,435(23.5)$ & $3,111(77.2)$ & $22,063(96.6)$ & $5,418(31.6)$ \\
Culture & $27,609(80.9)$ & $67,899(82.2)$ & $3,415(84.8)$ & $22,493(98.5)$ & $15,892(92.8)$ \\
HIV serology & $27,224(79.8)$ & $58,482(70.8)$ & $3,401(84.4)$ & $22,673(99.3)$ & $15,487(90.4)$ \\
Treatment outcome & $27,524(80.7)$ & $51,052(61.8)$ & $3,673(91.2)$ & $22,354(97.9)$ & $16,130(94.1)$ \\
\hline
\end{tabular}

aValues expressed as $n(\%)$. Source: Brazilian National Ministry of Health/Department of Health Surveillance/Brazilian Case Registry Database; data collated by the authors.

Although the degree of completeness was high for the variable "HIV serology" (classified as category 3 in one capital and as category 4 in the other ones), it was low for the variable "HIV co-infection". For the variable "HIV serology", the proportion of fields that read "not performed" ranged from $22.9 \%$ to $65.3 \%$, which is in disregard of the recommendation of the Brazilian National Ministry of Health that all tuberculosis patients should undergo HIV testing. ${ }^{(10)}$ In Brazil, the number of cases of tuberculosis has increased by $12 \%$ since the beginning of the AIDS epidemic, and the risk of an unfavorable outcome (treatment failure, multidrug resistance, and mortality) is approximately three times higher in tuberculosis patients who are co-infected with HIV than in those who are not ${ }^{(11)}$ and can be as high as 55.0\%. (12) Incomplete data on treatment outcomes and HIV infection can be reconstructed using the linkage (relationship between records) technique, ${ }^{(13)}$ comparing records among the Brazilian National Mortality Database, the Brazilian National CD4+/ CD8+ T Lymphocyte Count and Viral Load Network Laboratory Test Control System, the Logistic
Medication Monitoring System, and the SINAN/ AIDS. However, this and other techniques for retrieval of epidemiological data have not been incorporated into the routine of the technicians at the state or regional health departments, and it is more feasible to invest in improving the degree of data completeness on the SINAN forms.

One of the five pillars upon which directly observed treatment stands is the implementation of a network database for collating information on case detection, treatment outcomes, and the performance of the control program. ${ }^{(14)}$ Low degrees of completeness reflect operational inadequacies of the PNCT and limit the analysis of information from health databases, which can negatively affect interventions aimed at tuberculosis control.

In the 2004-2007 period, the Brazilian government invested in training, allocated more resources for PNCT database operation, and instituted a system of rewards for priority cities where the degree of completeness for treatment outcome was higher than 90\% in 2004 and for those where $75 \%$ of that goal was met in 2006. ${ }^{(15)}$ Nevertheless, possible explanations 
for the low degree of completeness observed in these cities are related to inadequacies in the number of health care staff and in the information technology infrastructure, hindering the flow and updating of information. In addition, the health care teams might view the filling out of forms as a bureaucratic chor, dissociating it from the quality of care. Therefore, it is recommended that the information technology infrastructure be improved and that the health care staff be trained and sensitized.

The present study has limitations, such as the use of secondary data and the limited number of variables of interest. However, the results obtained are relevant because we evaluated 18\% of approximately 900,000 cases of tuberculosis reported in Brazil in the last ten years.

In conclusion, our evaluation of these five capitals over a ten-year period shows that the degree of completeness of reporting forms is lower than that recommended by the Brazilian National Ministry of Health. This situation can affect the quality of the PNCT, given that it has negative consequences for health care and decisionmaking processes, which suggests an urgent need for the implementation of innovative strategies that can increase the degree of completeness of tuberculosis reporting forms at all levels (national, state, and municipal).

\section{References}

1. World Health Organization. Global tuberculosis control: WHO report 2011. Geneva: World Health Organization; 2011.

2. Portal da Saúde [homepage on the Internet]. Brasília: Ministério da Saúde. [cited 2012 Jan 24]. Notícias. Available from: http://portal.saude.gov.br/portal/aplicacoes/noticias/ default.cfm?pg=dspDetalheNoticiactid_area $=124 \mathrm{ECC}$ _ NOTICIA $=1165$

3. DATASUS [homepage on the Internet]. Brasília: Ministério da Saúde. [cited 2012 Jan 24]. Taxa de Incidência de
Tuberculose. Available from: http://tabnet.datasus.gov. br/cgi/tabcgi.exe?idb2011/d0202.def

4. Brasil. Portaria GM/MS no 2325 de 08 de dezembro de 2003. Define a relação de doenças de notificação compulsória para todo território nacional. Diário Oficial da União. Brasília, $n^{\circ}$ 240, p. 81, 10 de dezembro de 2003. Seção 1.

5. Portal da Saúde [homepage on the Internet]. Brasília: Ministério da Saúde. [cited 2012 Jan 24]. 0 que é o Sinan. Available from: http://dtr2004.saude.gov.br/ sinanweb/index.php? name=Tnet

6. Portal da Saúde [homepage on the Internet]. Brasília: Ministério da Saúde. [cited 2012 Jan 24]. Nota técnica $n^{\circ}$ 15 CGPNCT/DEVEP/SVS/MS. [Adobe Acrobat document, 4p.]. Available from: http://portal.saude.gov.br/portal/ arquivos/pdf/nota_tecnica_prioritarios.pdf

7. Braga JU. Tuberculosis surveillance and health information system in Brazil, 2001-2003 [Article in Portuguese]. Rev Saude Publica. 2007;41 Suppl 1:77-88.

8. Moreira CM, Maciel EL. Completeness of tuberculosis control program records in the case registry database of the state of Espírito Santo, Brazil: analysis of the 2001-2005 period. J Bras Pneumol. 2008;34(4):225-9.

9. Ministério da Saúde. SINAN - Relatórios - Manual de operação. Brasília: Ministério da Saúde; 2012.

10. Brasil. Ministério da Saúde. Secretaria de Vigilância em Saúde. Departamento de Vigilância Epidemiológica. Manual de recomendações para o controle da tuberculose no Brasil. Brasília: Ministério da Saúde; 2011.

11. Sanchez M, Bartholomay P, Arakaki-Sanchez D, Enarson D, Bissell K, Barreira D, et al. Outcomes of TB treatment by HIV status in national recording systems in Brazil, 2003-2008. PLoS One. 2012;7(3):e33129.

12. Oliveira HB, Marín-León L, Cardoso JC. Perfil de mortalidade de pacientes com tuberculose relacionada à comorbidade tuberculose-aids. Rev Saude Publica. 2004;38(4):503-10.

13. Almeida MA, Alencar GP. Informações em Saúde: Necessidade de Introdução de Mecanismos de Gerenciamento dos Sistemas. Informe Epidemiológico do SUS. 2000;9(4):241-48.

14. Brasil. Ministério da Saúde. Secretaria de Vigilância em Saúde. Departamento de Vigilância Epidemiológica. Guia de vigilância epidemiológica. Brasília: Ministério da Saúde; 2009.

15. Santos J. Brazilian response to tuberculosis control [Article in Portuguese]. Rev Saude Publica. 2007;41 Suppl 1:89-94. 


\section{About the authors}

Normeide Pedreira dos Santos

Doctoral Student. Graduate Program in Medicine and Health, Bahia School of Medicine and Public Health, Salvador, Brazil.

Monique Lírio

Resident in Infectious Diseases. Federal University of Bahia, Salvador, Brazil.

Louran Andrade Reis Passos

Medical Student. Bahia School of Medicine and Public Health, Salvador, Brazil.

Juarez Pereira Dias

Physician. Epidemiological Surveillance, Bahia State Health Department, Salvador, Brazil.

\section{Afrânio Lineu Kritski}

Full Professor. Tuberculosis Academic Program. Federal University of Rio de Janeiro School of Medicine, Rio de Janeiro, Brazil.

\section{Bernardo Galvão-Castro}

Physician-Researcher. Graduate Program in Medicine and Health, Bahia School of Medicine and Public Health, and Advanced Laboratory of Public Health, Gonçalo Moniz Research Center, Oswaldo Cruz Foundation-Bahia, Salvador, Brazil.

\section{Maria Fernanda Rios Grassi}

Physician-Researcher and Advisor. Graduate Program in Medicine and Health, Bahia School of Medicine and Public Health, and Advanced Laboratory of Public Health, Gonçalo Moniz Research Center, Oswaldo Cruz Foundation-Bahia, Salvador, Brazil. 